\title{
Serotonin Measurement
}

National Cancer Institute

\section{Source}

National Cancer Institute. Serotonin Measurement. NCI Thesaurus. Code C74872.

The determination of the amount of serotonin hormone present in a sample. 